\title{
Managing Access to Public Information Conflicts. Is Mediation a Solution? Lessons from the Catalan Experience ${ }^{1}$
}

\author{
Agustí Cerrillo Martínez ${ }^{2}$ \\ Clara Isabel Velasco Rico ${ }^{3}$
}

\section{ABSTRACT}

Access to public information often creates conflicts particularly when Public Administration rejects information requests. This research article examines the application of mediation to conflicts related to the right of access to documentation and public information in five selected different countries and regions from Europe and North America. It develops a study of the first autonomic regulation in Spain, Catalan Act 19/2014, of December 29, which has provided

1 A previous version of this text was presented at the Congreso anual de la Asociación Española de Profesores de Derecho Administrativo Universidad de Zaragoza (2016) and was included in the proceedings of the Congress. Las vías administrativas de recurso a debate. Actas del XI Congreso de la Asociación Española de Profesores de Derecho Administrativo, Zaragoza, 5 y 6 de febrero de 2016. The text has been significantly modified and updated since then.

2 Doctor en Derecho. Catedrático de Derecho Administrativo en la Universitat Oberta de Cataluña, Barcelona, España. Correo-e: acerrillo@uoc.edu. Enlace ORCID: https://orcid. org/0000-0002-1577-4194.

3 Doctora en Derecho. Profesora Agregada de Derecho Administrativo en la Universitat Pompeu Fabra, Barcelona, España. Correo-e: clara.velasco@upf.edu. Enlace ORCID: https:// orcid.org/0000-0001-9289-7676. Fecha de recepción: 9 de enero de 2020. Fecha de modificación: 18 de febrero de 2020. Fecha de aceptación: 2 de mayo de 2020. Para citar el artículo: Cerrillo Martínez, Agustí, Velasco Rico, Clara Isabel, "Managing access to public information conflicts. Is mediation a solution? Lessons from the Catalan Experience", Revista digital de Derecho Administrativo, Universidad Externado de Colombia, n. ${ }^{\circ} 24,2020$, pp. 293-312. DOI: https://doi.org/10.18601/21452946.n24.12. 
an alternative mechanism to solve conflicts in this area. This compared analysis aims to shed light on the use of mediation in conflict resolution concerning access to public information to identify its benefits, but also its limitations.

Keywords: Mediation, Transparency, Access to Public Information, Conflict, Comparative Analysis.

\section{Gestionando conflictos de acceso a la información pública. ¿Es la mediación una solución? Lecciones de la experiencia catalana}

\section{RESUMEN}

El acceso a la información pública genera de forma frecuente conflictos, particularmente cuando la Administración rechaza las solicitudes de acceso. Este artículo se centra en el análisis del uso de la mediación en conflictos relacionados con el acceso a la documentación y a la información pública en cinco países y regiones de Europa y Norte América. En especial, se estudia la primera norma autonómica española, la Ley catalana 19/2014, que ha establecido un mecanismo de resolución alternativa de conflictos en este ámbito. Este análisis comparativo arroja luces sobre el uso de la mediación en la resolución de conflictos relativos al acceso a la información pública e identificar sus beneficios, pero también sus limitaciones

Palabras clave: mediación, transparencia, acceso a la información pública, conflicto, análisis comparado.

\section{INTRODUCTION}

Access to public information often creates conflicts: Public Administration rejects information requests, gives different information than requested or simply ignores information requests.

These conflicts can be solved using traditional resolution procedures (i.e. administrative and judicial appeals). However, these procedures are costly, both in economic and time terms, for the person requesting information and the Public Administration that possesses it Mediation is one of the techniques included in the line-up of the so-called alternative dispute resolution (ADR) means. ${ }^{4}$

Mediation is a conflict resolution procedure where a third party, who does not have the authority to impose an outcome on disputing parties, helps the 
interested parties reach a mutually accepted agreement to solve the conflict. ${ }^{5}$ As the European Code of Conduct for Mediators states, mediation means any structured process, regardless of its name, whereby at least two parties, in an attempt to solve a dispute, are voluntarily willing to reach an agreement on the solution of their conflict with the help of a third party (... ' 'the mediator'. ${ }^{6}$

A key defining factor of mediation is the presence of a third party. A third party is defined as "a third individual who is neutral and impartial". ${ }^{7}$ The role of this third party, namely the mediator, is to offer another approach, a different one, to conflictive human relations. ${ }^{8}$

Mediators interrelate with the parties involved in the conflict, give information, suggest essential items to debate, and keep control of the most important elements of the procedure (dates, gathering information, type of interaction between the parties, etc.). It is also important to emphasize that any of their moves can conditionate the whole process or even its final result. ${ }^{9}$ The mediator helps people to understand their situation and the ultimate criterion of effectiveness or success of this task is whether or not the intercession achieves this objective. ${ }^{10}$ However, it has to be highlighted that mediation is about allowing and giving power to people to make their enlightened choices, more than having a third party making a decision for them. ${ }^{11}$

Mediation has different advantages in comparison to other dispute resolution procedures, such as reducing the time and cost to process and resolve conflicts; flexibility in solving conflicts or the effectiveness of the solutions since they are accepted by both parties. Another advantage of this ADR mechanism is that the mediation procedure encompasses a rare quality for changing difficult communication and, as a consequence, altering the attitude of

5 Stephen B. Goldberg, Jeanne M. Brett, and Beatrice Blohorn-Brenneur, How mediation works: Theory, research, and practice, Bingley: Emerald Publishing Limited, 2017, p. 15.

6 The text of the Code can be accessed here: https://ec.europa.eu/civiljustice/adr/adr_ec_ code_conduct_en.pdf (last visit, 24.07.2019).

7 JaCQUeline Deschamps, Mediation: A Concept for Information and Communication Sciences, Hoboken, New Jersey: John Wiley \& Sons, 2019, p.18.

8 Ibid.

9 Sydney E. Bernard, Joseph P. Folger, Helen R. Weingarten, and Zena R. Zumeta, "The neutral mediator: Value dilemmas in divorce mediation", Mediation Quarterly, vol.4, 1984, p.66.

10 Dorothy J. Della Noce, Robert A. Baruch Bush, and Joseph P. Folger, "Clarifying the theoretical underpinnings of mediation: Implications for practice and policy", Pepperdine Dispute Resolution Law Journal, vol. 3, 2002, p. 39.; THOMAS A. KoCHAN and TOOD Jick, "The public sector mediation process: A theory and empirical examination", College Park-Mariland Journal of Conflict Resolution, vol. 22, n. ${ }^{\circ} 2,1978$, p. 11.

11 Suzanne McCorkle and Melanie J. Reese, Mediation theory and practice, Newbury Park (CA): Sage Publications, 2018, p. 1. 
individuals who are tangled up in the conflict. ${ }^{12}$ However, it is not clear that the solutions are equivalent or better. ${ }^{13}$ In this sense Burns states that "It is almost certainly true, however, that in the majority of mediations, at least one of the participants, if not both, is a person of modest means". ${ }^{14}$

Despite the advantages that have often been highlighted, reality shows how this method of conflict resolution is not spreading significantly among the Public Administration.

Mediation as a conflict resolution procedure is praised to be an extended tradition in different cultures and countries. ${ }^{15}$ It also has several applications to solve conflicts in different fields (family, community, victim-offender, organizational, ...).

But mediation has not been widely used in government, at least among southern European Public Administrations (namely Italy, Spain, France and Greece). However, since the mid-1970s there have been some mediation experiences in government particularly in the environmental sector which have been included in some regulations (i.e. United States Negotiated Rulemaking Act of 1990 and the Administrative Dispute Resolution Act of 1990). ${ }^{16}$

There are limits to the use of mediation from the perspective of Comparative law, as has been emphasized. The most significant of these limits is that this alternative dispute resolution technique may only be used when there is a possibility of negotiation. When this negotiation aspect does not exist, mediation cannot be used, evidently. ${ }^{17}$ In addition, in certain legal systems, such as in Germany, mediation may be used when the acting Administration is exercising discretionary authority, but not in the case of regulated authority. The Spanish system also seems to favor this option. In this case mediation may be used "within the framework of the Administration's conventional activity, within a discretionary space ${ }^{\prime \prime}{ }^{18}$ In other systems, such as the British system,

12 Joseph P. Folger and Robert A. Baruch Bush, The promise of mediation: The transformative approacb to conflict. New Jersey: John Wiley \& Sons, 2004, p. 22.

13 Susan S. Silbey, "The Emmperor's New Clothes: Mediation Mythology and Markets", Journal of Dispute Resolution, vol. 1, 2002, p. 173.

14 Robert P. Burns, "Some ethical issues surrounding mediation", Fordham Law Review, vol. 70, 2001, p. 691.

15 JACQUeline Deschamps, op. cit., p. 8.

16 Robert ZeInEMAnN, "The characterization of public sector mediation", in Jacqueline Deschamps. Mediation: A Concept for Information and Communication Sciences, Hoboken (NJ): Environs: Environmental Law and Policy Journal, 2000, p.50.

17 Alfonso MASUCCI, "El procedimiento de mediación como medio alternativo de resolución de litigios en el Derecho administrativo. Esbozo de las experiencias francesa, alemana e inglesa", Revista de Administración Pública, vol. 178, 2009, p. 18.

18 Jaime Rodríguez Arana, "La mediación en el Derecho Administrativo", Revista de Derecho Público, n. ${ }^{\circ} 74,2011$, p. 463. 
mediation is not acceptable to solve disputes related to civil rights and liberties or alleged abuse of power by the Public Administration. ${ }^{19}$

Therefore, conflicts related to the right to access public information should be excluded from the legitimate scope of mediation, in principle. ${ }^{20}$ Nevertheless, and beyond shining a light on this critical view, this paper explores successful mediation experiences developed in different countries within the field of governmental transparency and access to public information.

This article approaches the practice of mediation within the field of access to administrative and public data, documents and information and assesses the limits of this mechanism to solve conflicts between the Public Administration and citizens. Firstly, we briefly analyze some successful experiences developed in foreign legal systems concerning the use of mediation to solve public information access controversies. Secondly, we address the study of the first autonomic regulation in Spain, Act 19/2014, of December 29, on Transparency, Access to Public Information and Good Governance, which has provided this alternative mechanism to solve conflicts in this area. Finally, based on the elements identified in previous sections, we research the limits to mediation as a mechanism to resolve conflicts concerning access to public information.

\section{MEDIATION CONCERNING ACCESS TO INFORMATION: COMPARED EXPERIENCES}

For the last decade, mediation has been a mechanism used for conflict resolution concerning access to public information in some countries. In fact, according to the Centre for Freedom of Information, $40 \%$ of the organizations ensuring the right to access information analyzed use mediation to solve complaints received concerning access to information. ${ }^{21}$

The use of mediation within this field aligns with the Recommendation by the Committee of Ministers of the Council of Europe regarding substitutes to litigation between public bodies and individuals or private parties [Rec(2001)9] where the authorities of Member States are summoned to encourage the use of ADR tools between administrative bodies and third parties in accordance with the principles indicated within the recommendation itself.

As will be seen below, mediation does not have the same scope in the different countries where this mechanism has been promoted to resolve conflicts

20 Ibid., p. 20.

21 Centre For Freedom Of Information, In the Experience of Information Commissioners. The Information Commissioners' International Exchange Network Survey 2014. Dundee (UK), 2014. 
concerning access to information. ${ }^{22}$ Indeed, the legislation and experience of mediation in conflict resolution concerning access to information in different countries shows how mediation does not have the same meaning, is not attributed to the same organizations, or have the same results.

In order to approach mediation in conflict resolution concerning access to information and know the scope of mediation, as well as the different procedures which can be used, four different models will be explored in this section: United States of America, United Kingdom, Quebec (Canada) and Switzerland..$^{23}$

\subsection{United States of America}

The US regulation of freedom of information is collected in the famous Freedom of Information Act (FOIA), passed in 1966.

This regulation has been subject to several modifications that aim to facilitate FOIA compliance by agencies. In particular, the Open Government Act modified the FOIA in 2007 to, among other aspects, create the Office of Government Information Services (OGIS) in the National Archives and Records Administration (NARA) and assign, among others, the duty to offer mediation services to solve disputes that may exist between the people requesting access and the agencies and emit advisory opinions in the case that mediation does not solve said disputes [(5 U.S.C. $\$ 552(\mathrm{~h})(3)]$.

OGIS is one of the five support offices at the core of NARA services. Despite being part of NARA, OGIS is afforded high independence. ${ }^{24}$ OGIS has an advisory committee comprising 20 members, half representing the Public Administration and the other half from outside the Administration. OGIS activity is closely related to that developed by the Office of Information Policy of the Department of Justice, which seeks to ensure that agencies comply with FOIA and is also in charge of defending them in litigations resulting from the application of FOIA. Likewise, it must also be taken into account that OGIS is not the only

22 Hugo Rojas Corral, "Aportes del derecho comparado a los sistemas alternativos de resolución de amparos del derecho de acceso a la información en Chile", Revista de Derechos Fundamentales, vol. 5, 2011.

23 See an analysis of mediation in England, Scotland and Ireland in Kevin Dunion and Huco Rojas CORRal, "Sistemas alternativos de resolución de conflictos y derecho de acceso a información pública: análisis de las experiencias escocesa, inglesa e irlandesa", Revista Transparencia \& Sociedad, vol. 3, 2015, pp. 69-91. With regard to the Chilean experience Hugo Rojas Corral, "Sistemas alternativos de resolución de amparos al derecho de acceso a información en el Consejo para la Transparencia", Revista de Derecho Público Iberoamericano, n. ${ }^{\circ} 8,2015$.

24 Mark H. GRUNEWALD, Reducing FOIA Litigation Through Targeted ADR Strategies. Washington: Final Report prepared for the consideration of the Administrative Conference of the United States, 2014, p.64. 
organization that can mediate conflicts concerning access to information that may arise, given that FOIA also attributes duties to mediate between people requesting information and agencies to FOIA Public Liaisons at the core of each agency [U.S.C. §552(a)(6)(B)(ii) and (I)].

In accordance with current legislation and the activity developed thus far by OGIS, it can be noted that the mediation that OGIS carries out includes different activities which are often complementary in nature: ${ }^{25}$

- Facilitation: informal and poorly structured mechanism to solve conflicts where OGIS personnel aid communication between the parties so that they understand their positions, interests or needs and help them identify common elements that allow them to resolve litigations satisfactorily without the formalities or costs of mediation. Facilitation may consist of reducing the scope of the request for information, encouraging agencies to reconsider their refusal decisions; obtaining more information on the processing of an access request or assisting agencies in their relationships with access applicants.

- Defense services: mechanism where OGIS personnel, given the complaints they receive, inform, advise, intercede or help solve questions received without getting to the bottom of the issue. A sign of the importance of this duty is that OGIS calls itself FOIA Ombudsman and aims to facilitate clear and direct communication between the access applicant and the agency where there is none.

- Mediation: mechanism where the mediator assists the disputed parties so that they find a solution that is mutually acceptable.

When mediation ends without the parties coming to an agreement, FOIA provides that OGIS may give an advisory opinion. This option may become a problem inasmuch as OGIS may position itself regarding an issue where it has previously participated as a mediator without the parties reaching an agreement, which may condition not only its credibility in this process, but also its neutral position in future procedures. ${ }^{26}$

With regard to the mediation procedure, although FOIA does not provide it explicitly, the guide written by the Office of Information Policy of the Department of Justice stipulates that agencies must incorporate a standard paragraph informing the applicant of the existence of OGIS mediation services, providing contact information, in the final resolution on requests for access to information. In any case, mediation is voluntary. FOIA provides that mediation is a non-exclusive alternative to lodging a judicial remedy for access applicants. But it does not specifically stipulate that it is mandatory for agencies to collaborate with ogIS during the mediation process. Thus, OGIS depends on the but Further Actions Are Needed, Washington: 2013. https://www.gao.gov/assets/660/657697. pdf.

Mark H. Grunewald, op. cit., p. 65. 
cooperation of agencies to succeed in its mediation role. Therefore, both the access applicant and the agency must agree to continue with this procedure as is usually the case. If one party does not agree, OGIS may encourage them to accept continuing with the mediation. Mediation will be carried out in accordance with the provision of the Administrative Dispute Resolution Act passed in 1996 [U.S.C. $\$ 571-84$ ].

During the mediation procedure, electronic means play an important role both by informing access applicants about the mediation process and because mediation can be requested by email.

In 2012, OGIS received 855 action requests of which around half where simple actions where OGIS assisted applicants over the phone or by email ${ }_{i} 46$ required facilitation and 239 only required defense services. Out of the 46 cases that requested facilitation services, 30 demanded mediation. Of these, $22 \mathrm{had}$ a positive outcome either because one or both parties acted or modified their position; they indicated that their satisfaction had improved or the issue was subsequently clarified, redirected or solved. ${ }^{27}$

The mediation model instituted at federal level through ocis is also present in around half of the states in the US that have introduced formal or informal mediation mechanisms with different success rates (competent body concerning access to information, ombudsman, mediation by the prosecutor's office, etc.). ${ }^{28}$

\subsection{United KingDom}

The Freedom of Information Act (FOIA) approved in the UK in 2000 provides that it is mandatory that the Information Commissioner Office (ICO) investigate complaints filed by citizens when they have been refused a request to access information [50 (1) FOIA].

FOIA does not stipulate a mediation procedure. Nevertheless, in practice, ICO personnel try to solve conflicts informally, facilitating the agreement between parties. Indeed, despite mediation not being explicitly included in FOIA, ICO develops this duty inasmuch as it has been identified as a good practice. ${ }^{29}$ If an agreement cannot be reached, ICO has the power to issue mandatory resolutions. $^{30}$ concrete figures are available. Nevertheless, we cannot ignore that the FOIA reform in 2016 significantly increased OGIS' activity.

28 David Cuillier and Charles N. Davis, The Art of Access: Strategies for Acquiring Public Records: Strategies for acquiring public records, Washington: CQ Press.

29 Kevin Dunion and Hugo Rojas Corral, op. cit., p. 75.

30 See https://ico.org.uk/for-organisations/guide-to-freedom-of-information/complaints/ (last visit: January 2019). 
Out of 5433 complaints processed in 2017-2018, 23\% were solved informally while $25 \%$ received a formal decision from ICO. In the remaining cases, the complaints were denied for different reasons. ${ }^{31}$

\subsection{Quebec (CAnAda)}

In Quebec, access to information is regulated by the Act respecting Access to documents held by public bodies and the Protection of personal information (LAI) and the Act respecting the protection of personal information in the private sector (LP).

These regulations confer the Commission d'Accès à la Information du Quèbec (CAI) the role of ensuring their correct application. ${ }^{32}$ CAI includes the jurisdictional section or administrative court (art. 134.1 and ss. LAI and $41.1 \mathrm{LP}$ ) and the monitoring section (art.122 and ss. LAI and 80 and ss. LP). As well as resolving demands made, the administrative court has also been conferred mediation duties. Specifically, CAI may entrust someone to try to make parties come to an agreement (art. 138.1 LAI and $48 \mathrm{LP}$ ).

When CAI receives a demand, a mediator is offered to the parties, free of charge, who helps them come to an agreement by themselves.

Mediation is a free and voluntary procedure which is confidential in nature. It is completely different from the decision-making procedure, though they can be processed together. Therefore, everything that has been expressed throughout the mediation cannot be communicated to those who will subsequently resolve the appeal and cannot be provided as evidence unless both parties consent. ${ }^{33}$

The mediation procedure follows the usual phases: the mediator interviews each party to inform them of the aims of the mediation, to know their position, as well as understand the position of the other party; the options are assessed, negotiated and satisfactory solutions for both parties are searched for. ${ }^{34}$ The mediation is often carried out over the phone to speed it up.

If the parties come to an agreement, this ends the appeal before the CAI. If, in contrast, an agreement is not reached, the parties may present their defense statements before a member of the CAI in an audience called to this effect and in this case, the normal procedure provided in current legislation is followed.

31 Information Commissioner's Office. Information Commissioner's Annual Report and Financial Statements 2017-18. Londres: 2018.

32 Clara I. Velasco Rico, "Reconocimiento y protección del derecho de acceso a los documentos públicos en Quebec. Especial referencia a la Comisión de Acceso a la Información", Revista Catalana de Dret Públic, vol. 50, 2015.

33 Reno Bernier and Gaston FréCHETte, "La médiation à la Commission d'Accès à l'Information. Une solution gagnante!", in Proceedings of the Congrès de l'Association sur l'accès et la protection de l'information, Québec, 2010, p. 3.

34 Direction des Affaires Juridiques, Cadre d'exercice de la médiation, Québec: 2013. 
Currently, $75 \%$ of cases of access refusal are directed towards mediation. Particularly, in 2017-2018, 1,059 records were processed through this mechanism. Despite this procedure being faster, records processed through mediation take an average of 408 days. $^{35}$

\subsection{SWITZERLAND}

The Federal Act of December 17, 2004, on transparency regulates the right to access public information and assigns the Federal Data Protection and Information Commissioner (Eidgenössischer Datenschutz- und Öffentlichkeitsbeauftragter, EDÖB) the responsibility of directing a mediation procedure in the case of disagreement between individuals and federal offices and departments, among other duties.

In particular, before certain disagreements due to the result of an information access procedure, the interested parties (both the applicants and affected third parties) may request EDÖB mediation within 20 days (art. 13 Federal Act on transparency). Processing the mediation procedure suspends the issue of recommendations by EDÖв. In the case that no agreement is reached, EDÖB will issue a written recommendation directed at the interested parties within 30 days (art. 14 Federal Act on transparency).

The mediation procedure is informal. It is developed under the guidance of a mediator and can be performed in writing or verbally with the participation of one or all parties. In fact, since 2017, in order to speed up conflict resolution, mediation is performed verbally. This also aims to increase the number of agreements between parties. The mediator may make suggestions during the mediation (art. 12.2 Ordinance on the principle of transparency in the Administration of May 24, 2006). A specific period is not set for the resolution of the mediation procedure; only when a significant amount of work is required of EDÖB may the resolution be extended for a reasonable period of time (art. 12.a.2 Ordinance on transparency).

The Swiss experience concerning transparency is also positive. In 2017, out of 213 refusals of access to information in the federal administration, 79 requests for mediation were presented, representing $37 \%$ of the total number of refusals. In 47 cases, a consensual solution was found. At the same time, EDÖB issued 31 recommendations in those cases where no agreement could be reached between the parties. ${ }^{36}$ The extension of oral mediation has represented

35 Commission d'ACCÈs À L'Information, Rapport annuel de gestion 2017-2018, Québec: 2018, p. 33.

36 Préposé Fédéral À la Protection des Données et À la Transparence, 25e Rapport d'activités 2017/18, Berna: 2018. 
a significant decrease in mediation duration, with $59 \%$ of procedures lasting less than 30 days in 2017 in comparison to $11 \%$ until $2016 .^{37}$

\section{MEDIATION CONCERNING ACCESS TO INFORMATION IN CATALONIA}

\subsection{Mediation in the Regulation of access to public information in Catalonia}

Act 19/2014, of December 29, on transparency, access to public information and good governance (henceforth, LTBG) recognizes mediation as one of the mechanisms to resolve conflicts that may emerge concerning access to public information. Specifically, this regulation stipulates that the Comissio de Garantia del Dret d'Accés a la Informació Pública (Commission Guaranteeing the Right of Access to Public Information, GAIP) may resolve complaints concerning access to public information through a mediation procedure.

LTBG refers to the development regulation currently in Decree 111/2017, of July 18, which approves the Reglament de la Comissió de Garantia del Dret d'Accés a la Informació Pública (Regulation of the Commission Guaranteeing the Right of Access to Public Information, RGAIP)..$^{38}$

The Catalan LTBG (LTBGCat) stipulates that express or presumed resolutions dictated regarding the right to access public information may be subject to free and voluntary complaint before GAIP (arts. 38 and 39.1). GAIP is a body without its own legal personality in accordance with the Act, that must fulfill its duties with complete organic and functional independence and is not subject to hierarchical instructions (art. 39.2). According to LTBG, GAIP will consist of at least three and a maximum of five members, designated by a majority of threefifths of the Members of Parliament (after appearing before the Chamber), among jurists or technical people concerning files of renowned prestige, with more than ten years' professional experience (art. 40.1 and 2).

The LTBG stipulates that people requesting public information may file a free and voluntary complaint before GAIP. Complaints may be processed through a mediation procedure or an ordinary procedure with resolution (art. 42.1 and 2). Mediation may be imposed by the claimant and the Administration cannot object to this option. This mediation procedure suspends the two-month

37 Préposé Fédéral à la Protection des Données et à la Transparence, Procédure de médiation selon la loi sur la transparence. Rapport d'évaluation de l'essai pilote 2017, Berna: 2018.

38 Additionally, the different elements defined within the RGAIP have been developed within the GAIP Manual de mediación (Mediation Manual), approved during the session on September 17, 2015. The Manual de mediación defines the guidelines and interpretative criteria that must guide the mediation procedure. 
period that GAIP must solve the complaint (art. 42.4). This procedure is a problem-solving mediation, not a transformative dispute resolution artifact. ${ }^{39}$

The mediator manages dialog and communication between the parties and helping them come to agreements regarding the access to information (art. 37.1 RGAIP). To this effect, the mediator must ensure that the parties have the necessary information and advice. The mediator is designated among the GAIP members and, subsequently, may not assume the instruction or participate in the deliberation phase or agreement proposal that terminates the procedure with resolution if the mediation does not end in an agreement. The mediator must assess if the agreement adopted by the parties contains elements contrary to the law.

The mediation procedure must ensure the principles of willingness, impartiality and neutrality, confidentiality and good faith (art. 36 RGAIP).

The mediation procedure followed before GAIP is structured in the usual mediation procedure phases (beginning, mediation session and agreement). The mediation procedure may be processed using electronic means if requested by the claimant and as long as all parties agree. The electronic means must ensure the authentication and identification of the participants, evidence of communication and the security, integrity and availability of the data and documents transferred (art. 21.4 RGAIP).

RGAIP regulates the mediation procedure in depth, which may end with an agreement, without an agreement, but calling another meeting and, if an agreement is reached, concluding the procedure (art. 40 RGAIP). The agreement reached must be approved by the claimant, the affected Administration and, if applicable, the third parties that appear on the record (art. 42.5 LTBG).

The minutes of the proceedings must clearly and concisely reflect the agreements that have been reached, if applicable, and must refer to the scope of access to information, the period for compliance and the conditions to put the access to information into effect. When the parties come to an agreement, GAIP must issue, within maximum two months from when the complaint was presented, a resolution stipulating that the agreements reached during the mediation procedure must be executed in the terms and periods provided and declaring the end of the procedure (art. 41.4 RGAIP). ${ }^{40}$

39 Robert Conduin, "The curious case of transformative dispute resolution: An unfortunate marriage of intransigence, exclusivity, and hype", Cardozo Journal of Conflict Resolution, vol.14, n. ${ }^{\circ} 3,2013$, pp. $621-681$.

40 As it has progressed in its activity, for some resolutions, beyond ordering compliance with the mediation agreement and declaring the end of the complaint procedure, GAIP assesses different issues both regarding procedural and substantive matters related to the complaint (competence to process the complaint, due diligence when processing information requests, requested information, transferring requests to affected third parties, administrative silence, express resolution of access requests, mediation process or monitoring of its resolutions). See resolution of November 19 (complaint 12/2015); resolution of November 
Obviously, this agreement terminates the complaint procedure and LTBC stipulates that it cannot, under any circumstances, be against the legal system (art. 42.5 LTBG). It must also be taken into account that the mediation agreement cannot be appealed by the signatory parties before the administrative justice, unlike resolutions made unilaterally by GAIP, the result of processing the complaint through the ordinary procedure (art. $42.8 \mathrm{LTBG}$ ). If the mediation procedure fails, or when one month has gone by since the procedure begun and no deal has been made, the Commission is required by law to process the complaint through a procedure processed "in accordance with the administrative appeal regulations" (art. 42.6 LTBG). In addition, GAIP may request data or reports that facilitate an agreement or, if applicable, become the basis for its resolution (art. 42.7 LTBG).

Additionally, the mediation agreement must stipulate the period for its execution and, where applicable, the conditions of access to information as well (art. 43.1 LTBG). If the Administration does not comply with the agreement (the Administration is obliged to communicate the actions performed to satisfy the agreement, art. $43.5 \mathrm{LTBG}$ ), the applicant may communicate this circumstance to GAIP so that it requires said compliance (art. 43.2 LTBG), under threat of applying the disciplinary measures disposed in Title VII of LTBGCat (art. 43.3 LTBG).

The scope of the mediation is particularly conditioned by the regulation where LTBG stipulates GAIP's duties. Specifically, LTBG stipulates that "the Commission must perform its duties through actions and agreements that are technical-legal in nature, that cannot, under any circumstances be motivated by opportunity or convenience criteria" (art. 39.3 LTBG). Given this legal requirement, it is surprising that mediation has been stipulated as an alternative to the ordinary complaint procedure, that is, to the procedure where GAIP imposes its decision on the parties in conflict through an exclusively technical-legal decision, which may be replaced, at the claimant's request, with an agreement between the parties, that would not necessarily have to deal exclusively with issues of a legal nature. In our opinion, if this is the case, it is because the legislator considers that the conflict, to determine whether the right to access certain public information exists or not and which is its scope, does not circumscribe to a dispute generated because of the interpretation of the regulations applicable to the case, but other elements present should also be resolved.

But this does not fully coincide with the provision that, in the case that the parties do not come to a mediation agreement within the prescribed time 
frame, it will be GAIP who may impose a solution on the parties, and the complaint will be processed through the ordinary procedure. In our opinion, the conflict between the parties does not change in nature: it is either a strictly legal conflict (which we are inclined to favor), or other opportunity or convenience issues are mixed together, which cannot be resolved by GAIP, in accordance with its regulations. If GAIP's role is restricted, in general, and in the complaint's ordinary processing, in particular, to strictly interpreting applicable regulations, GAIP will hardly be able to satisfy all present interests, if the conflict is considered to present opportunity or convenience elements. This would amount to admitting that the potential for resolving conflicts presented before GAIP and the applicable criteria vary, or are not symmetrical, according to the procedure to be followed. So that, in the case that the mediation procedure is followed, the agreement could encompass or take into account elements that exceed the strict application of the regulations-something we consider questionable, while the Administration affected by the request cannot compromise or reach an agreement regarding the application or not of the legal system to the specific case (the right to access either exists or does not)- Whereas, if the ordinary complaint path is selected, or the complaint is resolved, GAIP would only have to abide by the interpretation of the legal regulations applicable to the case to come to a resolution.

\subsection{THE MEDIATION EXPERIENCE AT GAIP}

To assess the scope of the mediation regulation concerning public information in Catalonia and know the impact of the limitations, it may be useful to refer to some data regarding the mediation activity performed by GAIP in the first three years of its operation (2015-2017).

TABLE 1. GAIP MEDIATION PROCEDURES (2015-2017)

\begin{tabular}{|l|c|c|c|c|c|c|}
\hline & \multicolumn{2}{|c|}{2015} & \multicolumn{2}{c|}{2016} & \multicolumn{2}{c|}{2017} \\
\hline Total complaints & 37 & $100 \%$ & 388 & $100 \%$ & 629 & $100 \%$ \\
\hline $\begin{array}{l}\text { Mediation procedure } \\
\text { requests }\end{array}$ & 20 & $54.05 \%$ & 41 & $10.56 \%$ & 159 & $25.27 \%$ \\
\hline Mediation sessions held & 12 & $32.43 \%$ & 27 & $6.95 \%$ & 44 & $6.99 \%$ \\
\hline Mediation agreement & 12 & $32.43 \%$ & 27 & $6.96 \%$ & 23 & $4 \%$ \\
\hline
\end{tabular}

* In the other cases, mediation was not performed for different reasons (the complaint was not admitted, the claimant ceased the mediation, the administration provided access to the requested information before holding the session).

Source: GAIP. 
As can be seen in the table, the number of complaints concerning access to public information filed before GAIP which are resolved through mediation is relatively low. Nevertheless, despite this we must recognize the role of this procedure, especially considering how new it is both within the Catalan Public Administration, in particular, and as a mechanism to resolve conflicts concerning access to public information. Also, the satisfactory results that they represent for claimants who have been denied access to public information by the Public Administration.

Beyond the number of mediation agreements, we cannot ignore the facilitation role that often results from the request by the claimant that their complaint be processed through the mediation procedure. Indeed, we should also keep in mind that "cases where, once the complaint has been presented before GAIP and the Administration is obliged to transfer the record and inform and legally justify its opposition to access, the Administration delivers the information subject to claim belatedly are not rare". In fact, in 2017, half of the complaints concluded due to unexpected loss of the object of the complaint because the right to access the information was belatedly given by the Administration. Thus, sometimes it is more a case of facilitating access to information than a mediation procedure in the strict sense of the word. Indeed, lodging a complaint, requiring a report on the complaint against the Public Administration and the call to the mediation session often constitute acts that cause the Public Administration who has been requested the public information to change its initial attitude (ignoring the request, denying access to information, etc.) and provide the information to the applicant. There is no doubt that this is all aided by GAIP's intervention.

Nevertheless, the Public Administration does not always comply with the agreements achieved during the mediation procedure. In this regard, we should keep in mind that LTBG stipulates that neglect by the Administration of GAIP's requirement to execute the mediation agreements may result in demanding the responsibility disposed in the regulation itself that categorizes deliberately hindering or obstructing the execution of mediation agreements as a highly serious infringement (art. 77.2.b LTBG). In 2017, GAIP considered it appropriate to require a town council to comply with the mediation agreement where they committed to delivering certain information to the claimant (Agreement 151/2017/PS of December 19, 2017).

Reading the mediation agreements reached between 2015-2017 does not allow us to know the aspects that were focused on during the mediation. It also does not allow us to know if during the mediation procedure a real compromise of interests is made to strike a deal, or if, as it seems, this procedure is taken advantage of to clarify the scope of the presented requests, for example.

In this case, mediation would be used for a purpose other than that for which it was intended, while a request improvement and completion procedure is already in place, at the beginning of the procedure, where the Public 
Administration is obliged to aid the applicant. If mediation proves useful in this case, it would be seen as an effective but not efficient tool, given that unnecessary time and resources belonging to both parties would be used to achieve it; time and resources which could have been saved if the request had been processed correctly at the beginning of the procedure.

Finally, we should highlight that claimants appreciate the information they receive regarding the mediation procedure; this aspect brought the greatest satisfaction in 2017 (4.14 out of 5). They also appreciate the usefulness of the mediation procedure ( 4.11 out of 5$).^{41}$

\section{CONCLUDING THOUGHTS}

The experiences of mediation in conflict resolution concerning access to public information analyzed above allow us to observe the potentialities of mediation in conflict resolution concerning access to public information as well as its utility and effectiveness. While the percentage of complaints resolved through mediation is variable according to each experience, in general terms, all cases provide significant figures.

The experience is positive inasmuch as mediation represents cost reductions, both in economic and time terms, for the person requesting information and the Public Administration that possesses it. Additionally, in general, mediation is easier both in terms of processing and resolving the conflict in question. In addition, mediation brings greater satisfaction both to the applicants requesting information and the agencies, not only because the conflict can be solved in the expected way but also because the parties consider that they have been heard, their needs have been taken into account, not only their positions, they feel understood and respected, they have been allowed to participate in the search for often creative solutions and have found themselves before a mediator that has accompanied them throughout this process.

Even though the term 'mediation' is used in all five experiences analyzed, in most cases it is an informal mechanism to solve conflicts concerning access to information by facilitating understanding between the claimant and the body that owns the information. Indeed, when "an impartial third party begins to help government officials, businesses and citizens involved in a public dispute, techniques of both mediation and facilitation are typically used". ${ }^{42}$ There are very few cases where a mediation procedure in the strict sense of the term is carried out, where an agreement between the parties is built on the substance of the case. In fact, in most cases analyzed, the informal nature of

41 Comissió de Garantia del Dret de Accés a la Informació Pública (Gaip), Memòria 2017, Barcelona: 2018.

42 John B. Stephens, "Using a mediator in public disputes", Public Management Bulletin, vol. 2 , 1998. 
the mediation is transferred to the means by which it is carried out, since mediation is often carried out over the phone or by email.

In any case, the extension of mediation in conflict resolution concerning access to information within the experiences that have been analyzed is a sign of the benefits derived from the use of this conflict resolution mechanism. Nevertheless, some limitations have also been identified, such as the lack of publicity that mediation procedures are often developed with. ${ }^{43}$ This lack of publicity, beyond affecting the procedure itself, limits the possibility of using agreements as precedent in subsequent cases. However, sometimes this circumstance has been valued positively since it ensures the confidentiality of certain information whose public knowledge may determine the refusal to access the information. ${ }^{44}$

Compared experience shows that mediation is used to reconsider decisions made, clarify misunderstandings, fix errors or solve mix-ups caused by thinking that the law was applicable to a particular case. In this case, if the mediator explains the regulation accurately or its interpretation by the guarantee body, this can lead to the parties coming to an agreement. To this effect, the mediator has a fundamental role in processing mediation procedures: they must have the right qualifications, in-depth knowledge of legislation, jurisprudence and practice on access to public information, have access to the necessary means and effectively be neutral and impartial.

Nevertheless, despite there being no precise data available in this regard, it does not seem that at the core of the mediation procedure a negotiation occurs between the person requesting the information and the body that owns it regarding substantive aspects of the regulation of the right to access public information such as reaching the limits of access. We consider that in transparency controversies the "zone of possible agreement" (ZOPA) is very narrow and limited to factual issues but not to legal ones.

This is the main limitation we observe with regard to the extension of this mechanism. Indeed, from a legal perspective, the use of mediation to resolve conflicts concerning access to public information may raise some doubts, as can be inferred from the experiences analyzed in the preceding pages.

Thus, it is remarkable that in some cases mediation has been considered an alternative to processing the interested party's complaint through a procedure equivalent to an administrative appeal. This is the case of the mediation carried out by GAIP which precisely occurs in the complaint stage before a body specialized in protecting the right to access public information; in this case, mediation is not preventing a conflict from appearing, but is used

43 Hugo Rojas Corral, "Aportes del Derecho Comparado a los Sistemas Alternativos...", op. cit., p. 86.

44 On all these issues, Kevin Dunion and Hugo Rojas Corral, "Sistemas alternativos de resolución de conflictos...", p.72. 
to resolve conflicts that already exist. As expected, in the case of mediation, GAIP plays a limited role, since it is restricted to facilitating the parties coming to an agreement. It should equally be noted, as we will see further on, that we are faced with a conflict that is, in our opinion, technical-legal in nature, derived from the different interpretation of the regulations sustained by the different parties (the person requesting access to the public information, the Administration who receives the request, and, as the case may be, the parties affected by the resolution).

It is also remarkable that mediation may be provided in relation to exercising regulated authority, when it may make more sense to use mediation in cases where the acting Administration is exercising discretionary authority. This would be the LTBG case that clearly sets out that when the limits to the right to access must be applied to a specific case there is no administrative discretion.

However, according to Harrison, there are some issues in mediation that might be problematic like that Administration can be less accountable, that some interest may be left out or omitted, regulatory standards may be overridden to secure purely local, site-specific deals, non-accountable actors can gain undue influence or powerful interest can impose their will on weaken interest. ${ }^{45}$

In any case, while it is true that this is not a widely extended experience at a comparative level, the positive results obtained through mediation in conflict resolution concerning access to information should be valued in a positive way.

\section{BIBLIOGRAPHY}

Bernard, Sydney, E., Joseph, P. Folger, Helen R. Weingarten, and Zena R. Zumeta. "The neutral mediator: Value dilemmas in divorce mediation". Mediation Quarterly, vol.4, 1984 .

Bernier, Reno, and Gaston FréChette. "La médiation à la Commission d'Accès à l'Information. Une solution gagnante!". In Proceedings of the Congrès de l'Association sur l'accès et la protection de l'information, Québec, 2010.

Burns, Robert P. "Some ethical issues surrounding mediation". Fordham Law Review, vol. 70, 2001.

Bush, Robert A. Baruch, and Joseph P. Folguer. The Promise of Mediation: The Transformative Approach to Conflict. New Jersey: John Wiley \& Sons, 2004.

Centre For Freedom Of Information. In the Experience of Information Commissioners. The Information Commissioners' International Exchange Network Survey 2014. Dundee (UK), 2014.

45 John Harrison, "Environmental Mediation: the ethical and constitutional dimension", Journal of Environmental Law, vol. 9, n. ${ }^{\circ} 1,1997$, pp. 79-102. 
Comissió de Garantia del Dret de Accés a la Informació Pública (Gaip). Memòria 2017. Barcelona: 2018

COMmission D'Accès À L'INFOrmation. Rapport annuel de gestion 2017-2018. Québec: 2018.

Condlin, Robert. "The curious case of transformative dispute resolution: An unfortunate marriage of intransigence, exclusivity, and hype". Cardozo Journal of Conflict Resolution, vol.14, n. ${ }^{\circ} 3,2013$.

Cuillier, David, and Charles N. Davis. The Art of Access: Strategies for Acquiring Public Records: Strategies for acquiring public records. Washington: CQ Press.

Deschamps, JacQueline. Mediation: A Concept for Information and Communication Sciences. Hoboken, New Jersey: John Wiley \& Sons, 2019.

Direction des Affaires Juridiques. Cadre d'exercice de la médiation. Québec: 2013.

Dunion, Kevin, and Hugo Rojas Corral, "Sistemas alternativos de resolución de conflictos y derecho de acceso a información pública: análisis de las experiencias escocesa, inglesa e irlandesa", Revista Transparencia \& Sociedad, vol. 3, 2015

Folger, Joseph P., AND Robert A. BARUCH Bush. The promise of mediation: The transformative approach to conflict. New Jersey: John Wiley \& Sons, 2004.

gao (United States Government Accountability Office). Freedom of Information Act. Office of Government Information Services Has Begun Implementing Its Responsibilities, but Further Actions Are Needed, Washington: 2013. https:// www.gao.gov/assets/660/657697.pdf.

Goldberg, Stephen B., Jeanne M. Brett, and Beatrice Blohorn-Brenneur. How mediation works: Theory, research, and practice. Bingley: Emerald Publishing Limited, 2017.

Grunewald, Mark H. Reducing FOIA Litigation Through Targeted adR Strategies. Washington: Final Report prepared for the consideration of the Administrative Conference of the United States, 2014.

Harrison, John. "Environmental Mediation: the ethical and constitutional dimension". Journal of Environmental Law, vol. 9, n. ${ }^{\circ} 1,1997$.

Information Commissioner's OfFice. Information Commissioner's Annual Report and Financial Statements 2017-18. London: 2018.

Kochan, Thomas A., And ToOd Jick. "The public sector mediation process: A theory and empirical examination". College Park-Mariland Journal of Conflict Resolution, vol. 22, n. $^{\circ} 2,1978$. 
Masucci, Alfonso. "El procedimiento de mediación como medio alternativo de resolución de litigios en el Derecho administrativo. Esbozo de las experiencias francesa, alemana e inglesa". Revista de Administración Pública, vol. 178, 2009.

McCorkle, Suzanne, and Melanie J. Reese. Mediation theory and practice. Newbury Park (CA): Sage Publications, 2018.

Noce, Dorothy J. Della, Robert A. Baruch BUSH, and Joseph P. FOlGER. "Clarifying the theoretical underpinnings of mediation: Implications for practice and policy". Pepperdine Dispute Resolution Law Journal, vol. 3, 2002.

Préposé Fédéral à la Protection des Données et à la Transparence. 25e Rapport d'activités 2017/18. Berna: 2018.

Préposé Fédéral à la Protection des Données et à la Transparence. Procédure de médiation selon la loi sur la transparence. Rapport d'évaluation de l'essai pilote 2017. Berna: 2018.

Rodríguez Arana, Jaime. "La mediación en el Derecho Administrativo". Revista de Derecho Público, n. ${ }^{\circ} 74,2011$.

Rojas Corral, Hugo. "Aportes del derecho comparado a los sistemas alternativos de resolución de amparos del derecho de acceso a la información en Chile". Revista de Derechos Fundamentales, vol. 5, 2011.

Rojas Corral, Hugo. "Sistemas alternativos de resolución de amparos al derecho de acceso a información en el Consejo para la Transparencia". Revista de Derecho Público Iberoamericano, n. ${ }^{\circ}$ 8, 2015.

Silbey, Susan S. "The Emmperor's New Clothes: Mediation Mythology and Markets". Journal of Dispute Resolution, vol. 1, 2002.

Stephens, John B. "Using a mediator in public disputes". Public Management Bulletin, vol. 2, 1998.

Velasco Rico, Clara I. "Reconocimiento y protección del derecho de acceso a los documentos públicos en Quebec. Especial referencia a la Comisión de Acceso a la Información". Revista Catalana de Dret Públic, vol. 50, 2015.

ZeInemann, RoBert. "The characterization of public sector mediation". In Jacqueline Deschamps. Mediation: A Concept for Information and Communication Sciences. Hoboken (NJ): Environs: Environmental Law and Policy Journal, 2000. 